\title{
FROM INDUSTRY TO TOURISM: THE CASE OF LX FACTORY IN THE ALCÂNTARA DISTRICT (LISBON)
}

\author{
Luca ZARRILLI* \\ University “G. d'Annunzio” of Chieti-Pescara, Department of Economic Studies, Pescara, Italy, e-mail: luca.zarrilli@unich.it \\ Miguel BRITO \\ Escola Superior de Hotelaria e Turismo do Estoril (Estoril Higher Institute for Hotel and Tourism Studies), Portugal, e-mail: miguel.brito@eshte.pt
}

Citation: Zarrilli, L., \& Brito, M. (2021). FROM INDUSTRY TO TOURISM: THE CASE OF LX FACTORY IN THE
ALCÂNTARA DISTRICT (LISBON). GeoJournal of Tourism and Geosites, $39(4 \mathrm{spl}), \quad 1354-1362$.
https://doi.org/10.30892/gtg.394spl05-778

\begin{abstract}
In the past few years Lisbon has been through many changes, most of them related to the tourism growth. Alcântara is one of the neighbourhoods that became popular, once an industrial area that is presently experiencing a process of urban regeneration. Alcântara is probably the best district of Lisbon to recall the industrial era. At the same time, it has all the services that it needs to welcome visitors: diversity of tourist supplies; a vibrant image, trendy, but also authentic; a barycentric position between two well-known quarters (Baixa and Belém); a good accessibility, still being strengthened; a fast growth in accommodation supply. Arguably, an important role in the tourist development of Alcântara is played by the LX Factory, a former industrial area of around $23.000 \mathrm{~m}^{2}$, where important companies were located. LX Factory is considered a successful experiment of reconversion of an industrial space into a multifunctional complex, which still preserves the former factory atmosphere, although according to a contemporary formula. The LX Factory was inaugurated in 2008. It hosts de sign offices, art ateliers, start-ups, shops, restaurants, cafés, night clubs, co-working spaces, and even a hostel. It also hosts cultural activities, concerts, workshops, and a Sunday market of vintage and biological products. A previous research (Zarrilli et al., 2019) showed that LX Factory is by far the main tourist attractor of Alcântara. In this contribution, we will try to deeper investigate what we may call the LX Factory phenomenon, in terms of tourist image, flows, motivations and assessments. At this aim, a questionnaire was administered to a sample of shop owners located in its facilities. Conclusions allow us to understand LX Factory main issues from the shop owners' perspective, regarding the commercial activity, the current image, the people who visit it, and their opinion about the neighbourhood.
\end{abstract}

Key words: urban tourism, industrial heritage, urban regeneration, LX Factory, Alcântara

$* \quad * \quad * \quad * \quad * \quad *$

\section{INTRODUCTION}

Currently, in order to attract tourists, tourist destinations are competing through the creation and promotion of unique and distinctive images, which combine the physical characteristics of the city with its intangible aspects (Ashworth and Turnbridge, 2000; Orbasli, 2000; Kolb, 2006). At the same time, tourists perceive as more important those elements that reveal the cultural character of the destination: The urban landscape and architecture, the daily life of local communities and the gastronomy. Nowadays, tourists try to integrate themselves into the life of the local community and deepen their tourist experience by living like the locals. On the other hand, contemporary tourists do not travel only for leisure: often the main purpose of their trip is work (conferences and meetings) or visiting family and friends who live and work in another country. Tourism and mobility are therefore increasingly intertwined. This has led to the expansion and complexity of the offer, and also to the spatial and typological diversity of tourism products, constantly changing and evolving (Joaquim, 2019).

The tourism sector is therefore fundamental for the recovery of urban spaces and vital in the regeneration of cities. Although we are witnessing a gentrification of old neighbourhoods, at least in old quarters of Lisbon (Sequera and Nofre, 2018), tourism can be a regenerating force (Brito-Henriques, 1996; Tiesdell et al., 1996), which prevents the degradation of cities by introducing new functions that attract dynamic young people with different lifestyles and consumptions. The question therefore appears to be at least controversial, since "there is no consensus in the literature regarding the final balance sheet of the effects of tourism in the city and there are reasons to consider that demonizing tourist gentrification is a simplistic way of facing the problem" (Safara and Brito-Henriques, 2017: 71). Unlike gentrification, touristification is a process in which a place becomes an object of tourist consumption, thus leading to changes in that very place (Bondora, 2019). "Some authors argue that touristification in central urban areas is the result of the complete transformation of the urban space into a tourist space" (Sequera and Nofre, 2018: 846). Touristification includes cross-class displacement, class diversity, Disneyfication, depopulation, worsening of community live ability, transnational and local real estate market and risk investment funds, and temporary accommodation (Sequera and Nofre, 2018: 850). Therefore, not unlike many capitals and small towns in Europe, Lisbon has been through a process of touristification since the 1990's, first in the centre and then in more peripheric neighbourhoods such as Alcântara, where tourism recently emerged to substitute the old $19^{\text {th }}$

\footnotetext{
* Corresponding author
} 
century industries (Jansen-Verbeke and Lievois, 1999). Regeneration, which has become a priority in urban planning in the last thirty years, is considered by Hackworth (2006), among others, to be the distinctive political tool of the neo-liberal city. It is generally justified by the need to overcome the phase of decline associated with deindustrialisation, to promote economic recovery by adapting the city to the challenges of the new global economy and to counteract demographic involution and aging of the population by attracting new residents, in particular young people belonging to the creative elites. The requalification of the building heritage and the urban environment linked to the competitiveness and territorial marketing of the city is therefore a crucial issue in the regeneration policies and in the new planning and governance solutions associated with neoliberal urbanism (Tallon, 2010; Guimarães, 2016). In Portugal, tourism became a sort of lever for urban regeneration. After deindustrialisation, new tertiary activities appeared (Zukin, 2010). Initiatives to restructure urban spaces, as well as the gentrification of old quarters and central Lisbon (Mendes, 2013; Nofre, 2013), are now beginning to take over more peripheral areas, such as Alcântara, which is the object of this article (Figure 1).

Following the increasing tourist demand, the amount of lodging units (particularly apartments for tourist use) in the Alcântara district is multiplying. In fact, if the presence of tourists in Alcântara was rather sporadic until a few years ago, it is now becoming part of the daily life of the neighbourhood, according to a model successfully tested in similar cases of functional reconversion (Gelbman, 2007). The reason is that Alcântara neighbourhood is well located, between the Museum District of Belém and the city centre called Baixa. Easily accessible, it is served by various means of transport (tram, bus, and train) a situation that tends to improve with the arrival of the metro within a short time. Therefore, Alcântara may become one of the most visited areas in the city, partly due to the constant passage of tourists on their way to Belém. The authors of the present study have analysed the tourism trends both in Lisbon and in the Alcântara district (Zarrilli and Brito, 2013; Brito et al., 2015a; Brito et al., 2015b; Zarrilli and Brito, 2017; Zarrilli et al., 2019). In this paper, we

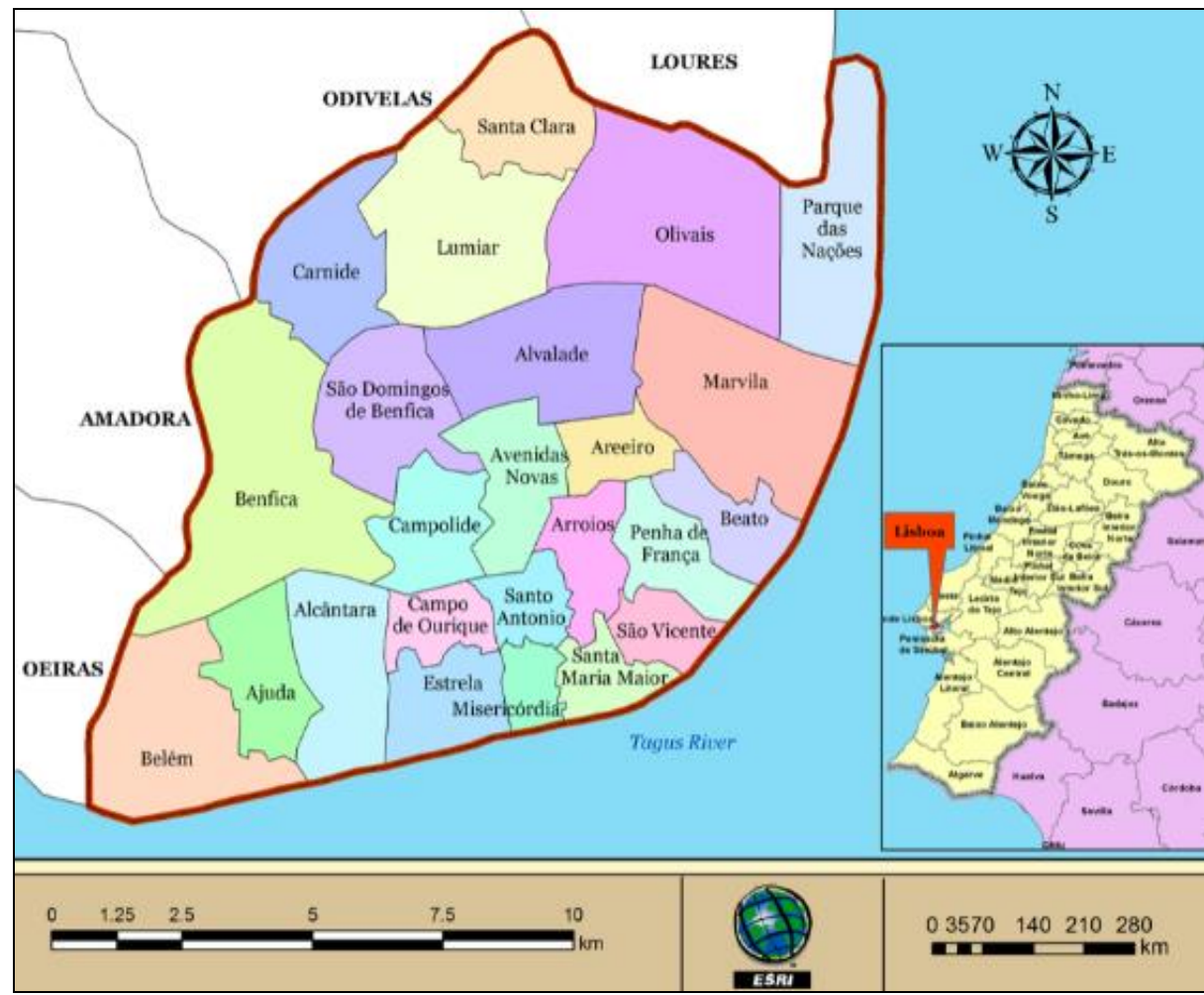

Figure 1. Lisbon's division into freguesias (districts) (Source: Zarrilli et al., 2019) emphasise the role that tourism can play in the transition from an urban industrial 'kind of life' to a post-industrial one (Bujok et al., 2014; Bujok et al., 2015), particularly in the case of LX Factory services and trade zone. For this purpose, a survey was conducted including two questionnaires: a questionnaire to the visitors, delivered in 2018 to a sample of 303 foreign tourists (see at this regard Zarrilli et al., 2019), and another one to the shop's owners, which will be analysed in detail further in this paper. The results of the two surveys allow us to hypothesize a rising future linked to the tourist services sector. Conclusions show that the LX Factory is becoming increasingly visited and becoming less peripheral in the mental map of tourists, on the one hand, and a good investment for those who own a shop or a restaurant there.

\section{Heritage regeneration, touristification and gentrification}

At first glance, Alcântara looks like an ex-industrial district dominated by buildings of different types, but relatively recent; among others, the Ponte 25 de Abril, the Docas de Santo Amaro (or simply Docas) warehouses, which are very popular today, and above all the modern CUF 2 hospital (Figure 2), which is a good case of what we can call healthcare gentrification. CUF 2 is a private hospital for the middle-upper class who can afford their own medical care. A closer look to the landscape, however, reveals a neighbourhood with an interesting and very diversified heritage dating from a large period between the sixteenth century and the present. Alcântara counts a population of 13,943 people (2014), and an area of $4.40 \mathrm{~km} 2{ }^{1}$. The oldest monument in Alcântara district is the chapel of Saint Amaro (Figure3), a pilgrimage destination from the $16^{\text {th }}$ century. Besides its outstanding glazed tiles, the chapel is currently known for the view over the whole neighbourhood and the river. In the $18^{\text {th }}$ century several churches were built, one of them dedicated to Saint Peter of Alcântara, as well as palaces that belonged to the Portuguese aristocracy, such as Ribeira Grande Palace and Burnay Palace, just to give two examples - a number of noble families moved to Alcântara because they wanted to be close to the royal family, who decided to live nearby, in Ajuda district, an area that was not destroyed by the earthquake of 1755 that

\footnotetext{
${ }^{1}$ https://www.jf-alcantara.pt/freguesia/
} 
destroyed the centre of Lisbon. From the beginning of $19^{\text {th }}$ century, Alcântara became the industrial area of Lisbon. Still today, the factory atmosphere prevails in the neighbourhood, where several units can be found. From 1966, when the bridge over the Tagus was built passing over Alcântara, the factories moved to the other side of the river while the bridge became the most significant landmark of Alcântara. It is possible to access to the top of the bridge - the entrance is at pier 7 (Pilar 7), where an exhibition on the construction of the bridge can be seen. Other attractions in the area are: The Docas (docks) near a marina under the bridge, where the old warehouses were converted into restaurants, bars, and night clubs; Lisbon Underground, with co-work spaces and start-ups, inspired in the British one; Museums such as Carris museum, where one can find old means of transport that run in Lisbon in the last two centuries; Macau Cultural Centre, with a library and an display focused on china porcelain and; Berardo Museum of Art Deco (also called BE MAD), a private collection that incudes very beautiful and sometimes delicate pieces in Art Nouveau and Art Deco styles.

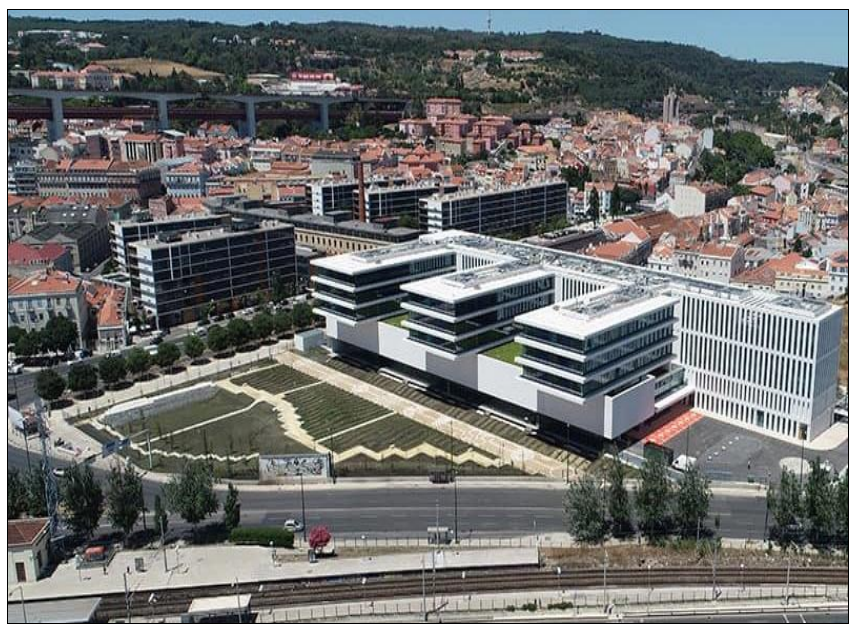

Figure 2. Hospital CUF 2 (Source: https://engexpor.com)

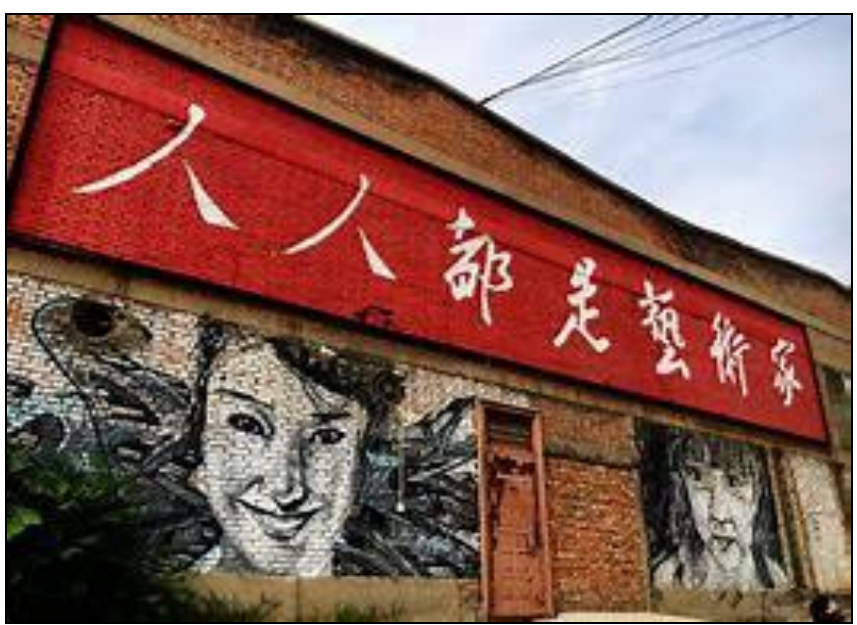

Figure 4. 798 Art Zone (Source: topchinatravel.com)

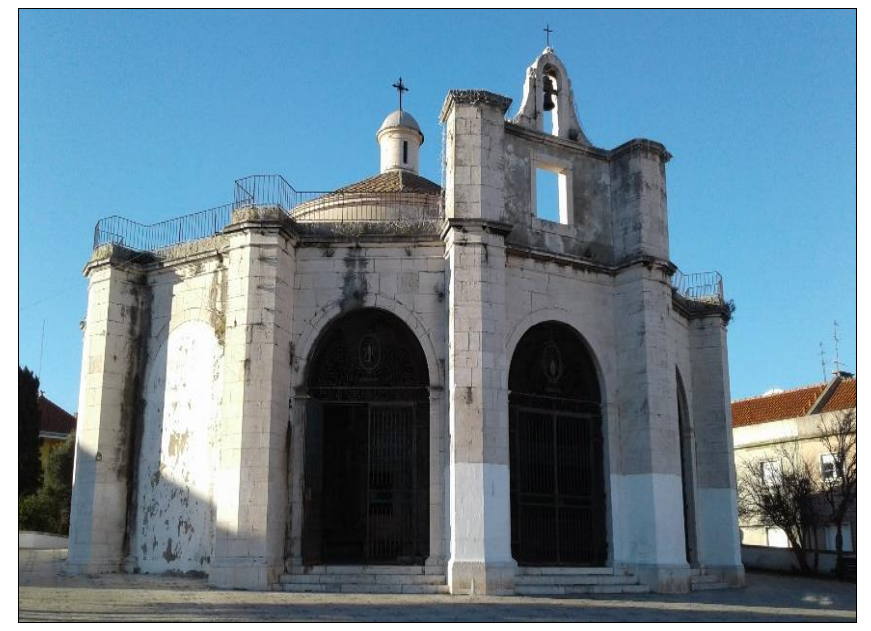

Figure 3. Chapel of Santo Amaro, Alcântaran (Source: authors)



Figure 5. Limits of LX Factory in Alcântara neighbourhood (Source: adapted from www.bing.com)

\section{The $L x$ factory}

Right in front of the Berardo museum is the key attraction in the neighbourhood: the LX Factory, an exciting instance of how an industrial complex can be converted into a multifunctional space. The concept is very similar to 798 Art Zone, in Beijing (Figure 4). LX Factory was inaugurated in 2008. It occupies a former industrial area of approximately $23,000 \mathrm{~m}^{2}$ and includes a main street and a secondary one with huge side buildings, previously branches of industrial businesses and/or their units (Figure 5). The area was reactivated by the Portuguese company Mainside Investments, preserving its original factory atmosphere, albeit according to a contemporary formula. In fact, about 200 offices, design studios and shops, art ateliers, start-ups, creative restaurants, cafes, bookshops, night clubs, co-working spaces and even a hostel, with a total occupancy of almost a thousand people can be seen and experienced today.

In 2017, the LX Factory was acquired by Keys Asset Management, a French company interested, according to analysts, in the profitability that an innovative formula such as the one embodied by the LX Factory can guarantee (Ferreira, 2017). The LX Factory hosts different events, cultural activities, workshops, concerts, and a Sunday market of vintage and organic products. It is a nice place to spend a Saturday night or Sunday morning, in a mood that some, like The Guardian newspaper (Moore, 2017), would define as cool (Figure 6). On this matter, the words of Xie may be quoted as follows: the LX Factory "experienced a process of gentrification from factory production to tourism" (Xie, 2015, p.174). "It is viewed as both an industrial icon and an ideal location for the logical transition to a service economy via the reinvention of traditions" (Xie, 2015: 191). For several years, Lisbon has been establishing itself as one of the most representative places 
in Europe for so-called street art, with many important examples in the Alcântara district. Some artists are now internationally famous, such as Vhils, Bordalo II, How and Nosm and AkaCorleone. They have performed works that are displayed on the facades of buildings and masonry throughout the neighbourhood, as well as inside the LX Factory and the Village Underground. From what has been said above, we can argue that there has been a clear tourism development in the Alcântara neighbourhood, including regeneration, touristification and gentrification.

Regeneration is related to heritage recovery (different kinds of industrial heritage and cultural issues) as well as to the foundation of new museums - Carris museum, Lisbon Underground, Macau cultural centre, Experience Pier 7, and Berardo museum are examples of that. Touristification can be noticed in the restauration supply of the Docas area, in the recently built hotels and local accommodation, or even in the attractive vibrant decoration of some shops and the nightlife in the LX Factory as well as in the presence of a new tourist office, strategically placed where tourist pass on their way from the railway station to LX Factory. Finally, three types of gentrification can be identified in Alcântara: Housing gentrification, including several new housing facilities and apartments; commerce and services gentrification, especially the Docas and LX Factory; and healthcare gentrification in the brand-new private hospital CUF 2.

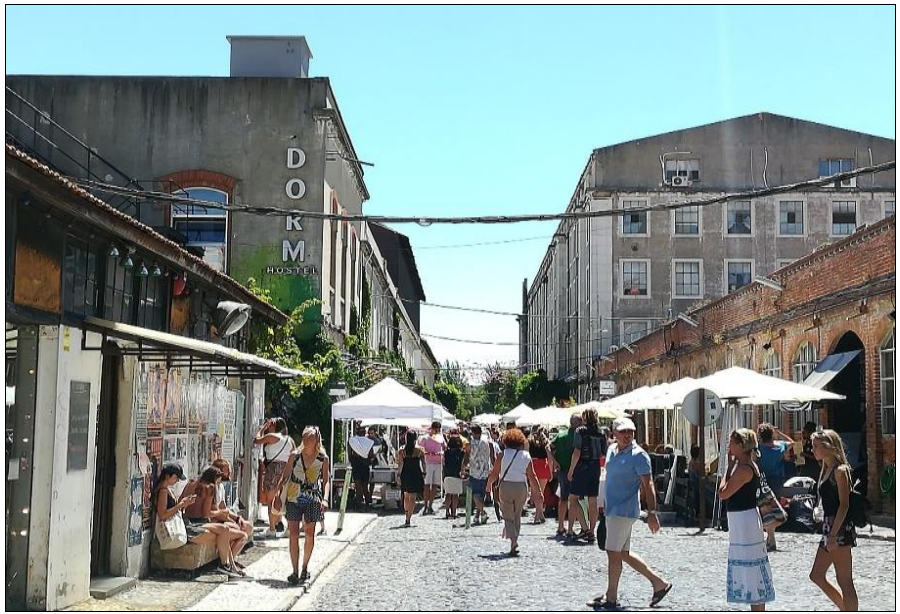

Figure 6. Sunday market in the LX Factory (Source: authors)

Table 1 - Accommodation facilities in Alcântara by $31^{\text {st }}$ December 2020(Source: own elaboration on data Turismo de Portugal - Registo Nacional de Turismo (Tourism of Portugal - National Tourism Register) $^{2}$

\begin{tabular}{|c|c|c|c|c|c|c|c|c|}
\hline \multicolumn{3}{|c|}{} & \multicolumn{3}{c|}{$\begin{array}{c}\text { Alojamento } \\
\text { local (Local } \\
\text { accommodation) }\end{array}$} & \multicolumn{3}{c|}{ Total } \\
\hline no. & rooms & beds & no. & rooms & beds & no. & rooms & beds \\
\hline 2 & 453 & 906 & 347 & 670 & 1,105 & $\begin{array}{c}26 \\
2\end{array}$ & 1,123 & 2,011 \\
\hline
\end{tabular}

\section{ACCOMMODATION FACILITIES}

In the Registo Nacional de Turismo (National Tourism Register) all the accommodation facilities in Portugal are sorted by year of opening and location. According to these data, there is evidence that a part of the housing stock of Alcântara has been reconverted into tourism facilities in the last few years. In addition to the two hotels in the district - large in size and of high quality - we can find an increasing number of accommodation facilities defined as alojamento local (local accommodation), consisting mostly of apartments that are rented to tourists for short periods. This phenomenon, also known as "airbnbsation" (see in this regard Sequera and Nofre, 2018: 850), in Alcântara consists of 347 non-hotel facilities ${ }^{3}$, with 670 rooms and 1,105 beds (Table 1). All the units started their activity after $1^{\text {st }}$ January 2015 , and over $75 \%$ of these (264) have been operational only since 2018 . In conclusion, the district of Alcântara can count an overall accommodation (hotel and non-hotel), as of $31^{\text {st }}$ December 2020, of 1,123 rooms with 2,011 beds, which confirms the increasing presence of Alcântara in the "mind map" and in the knowledge of tourists.

\section{METHODOLOGY}

The present research was based on a qualitative-quantitative approach. The qualitative study includes:

1) Direct observation of the investigated zone - field research took place between 2013 and 2020.

2) In situ information gathering from primary sources.

3) Literature review, with specific reference to

i) post-industrial tourism (Gelbman, 2007; Chmielewska and Lamparska, 2012; Xie, 2015; Bujok et al. 2014, 2015);

ii) Lisbon related research (Brito-Henriques, 1996; Mendes, 2013; Nofre, 2013; Tulumello, 2015; Muselaers, 2017; Barata Salgueiro et al., 2017; Safara and Brito-Henriques, 2017; Joaquim, 2019) and;

iii) Alcântara district related research (Marques de Abreu Pereira, 2009; Ribeiro, 2012; Rodrigues da Silveira, 2017; Vidal, 2014; Vidal, 2015), including Internet sites.

The quantitative research was based in data made available by institutional sources (Turismo de Portugal/Tourism of Portugal; Instituto Nacional de Estatística/National Institute of Statistics), and of a questionnaire delivered to shop owners, whose shops are in the LX Factory area. The questionnaire aimed at knowing the reasons for the shops' location choice, and the assessment of LX Factory, with reference to the tourist development of the latter and of Alcântara district in general.

\section{The survey}

The questionnaires were filled out by a random sample of 30 shop owners (out of a total number of 200 among stores, restaurants, snack bars, design studios, art studios, start-ups, nightclubs, co-working spaces, and a hostel) in the months of January and February 2020, just before the spread of the COVID-19 pandemic. Therefore, the results of the survey refer to a pre-pandemic situation from the points of view of national and international mobility and purchase decisions.

\footnotetext{
${ }^{2}$ https://registos.turismodeportugal.pt/HomePage.aspx, visited on $25^{\text {th }}$ August 2021

${ }^{3}$ Including the hostel "The Dorm", which is located inside the LX Factory
} 
The questionnaires delivered to shop owners consisted of four sections:

1. General information about their business (type and age of the activity; property regime; size of the shop; staff).

2. Assessment of LX Factory context (location factors; satisfaction with setting; main positive and negative aspects of LX Factory).

3. Customers (average number of visitors/customers during workdays, weekends and holidays; average percentage of foreign tourists out of the clientele; main countries/regions of origin of foreign tourists).

4. Alcântara neighbourhood (tourist potential and perspectives of Alcântara district).

\section{RESULTS AND FINDINGS}

General information - The kind of activity most represented in the sample is trade with 17 stores, followed by catering, with 11 units among restaurants and snack bars (Figure 7). This composition of the sample reflects the situation on the ground, characterized by a prevalence of specialized stores aimed at customers with a medium-high cultural and income level. The catering sector, on the other hand, mainly consists of ethnic or specialised restaurants and snack bars, suitable for a demanding and wealthy clientele. Most businesses are recent: 7 units out of 30 started their activity in 2019 or at the very beginning of 2020, while another 12 started between 1 and 5 years before the survey (Figure 8). This can be seen as a sign of the recent development of the LX Factory as a leisure destination, both for residents and tourists.

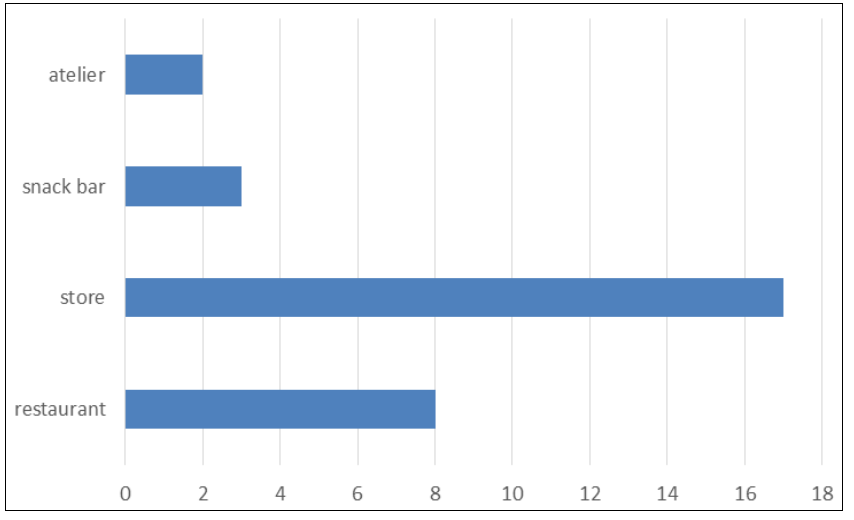

Figure 7. Type of activity/no. of units (Source: authors)

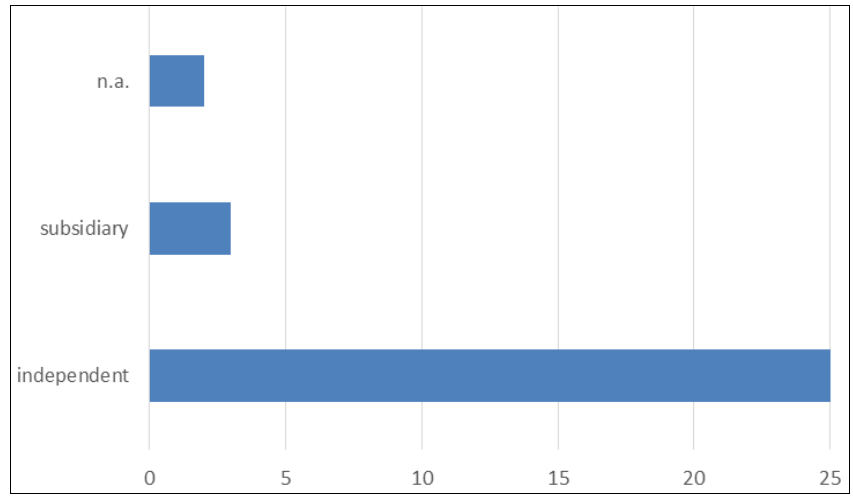

Figure 9. Property regime/no. of units (Source: authors)

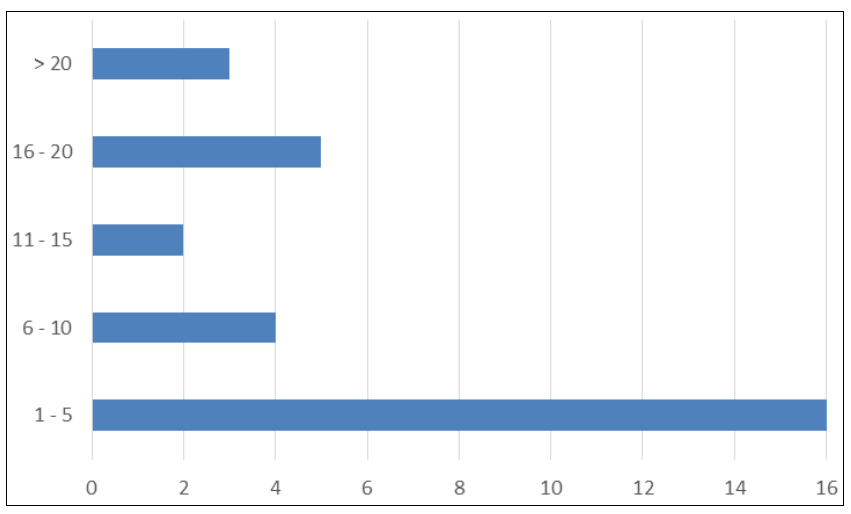

Figure 11. No. of personnel/no. of units (Source: authors)

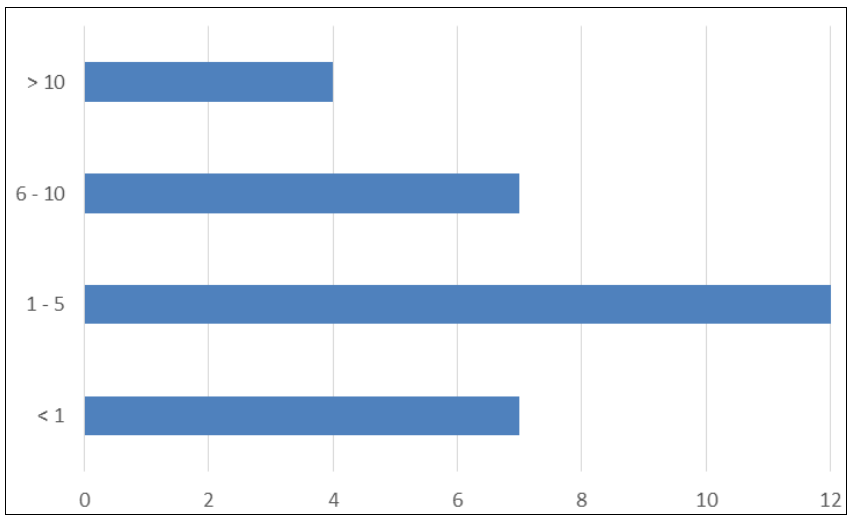

Figure 8. Years of activity/no. of units (Source: authors)

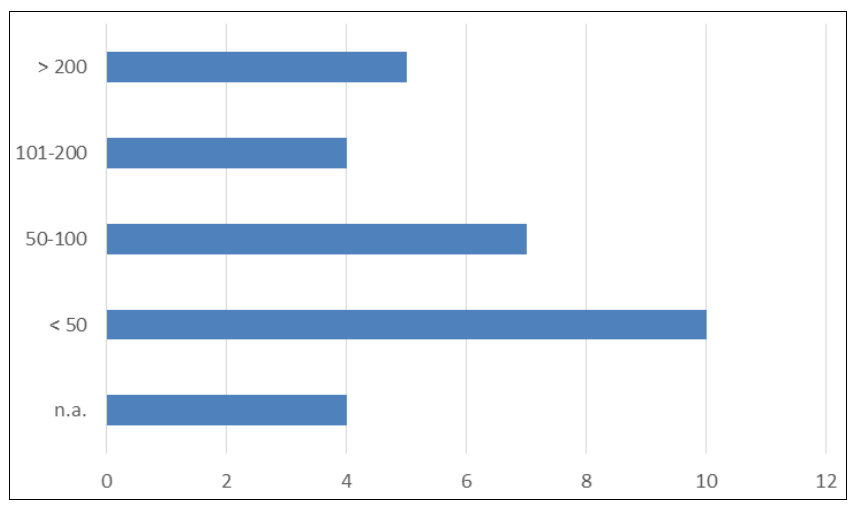

Figure 10. Size $\left(\mathrm{m}^{2}\right) /$ no. of units (Source: authors)

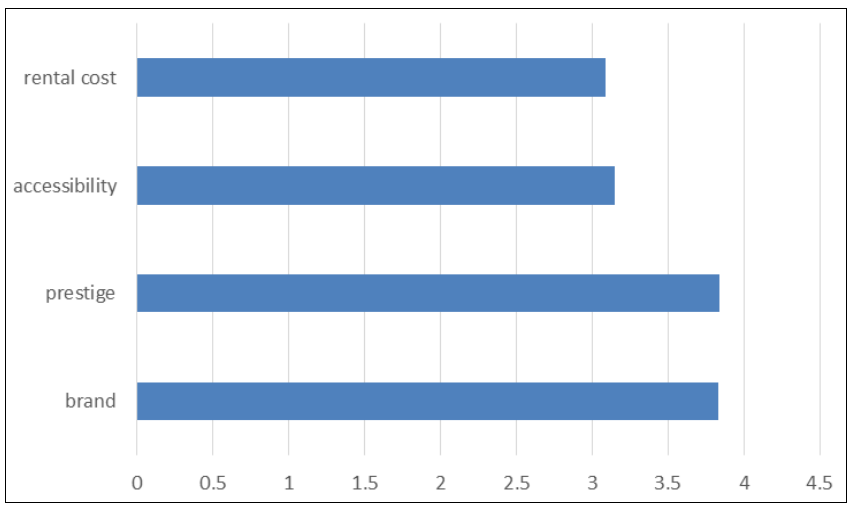

Figure 12. Localisation factors/assessment (Source: authors)

The great majority of the sample is independent from the point of view of the property regime (Figure 9) and small, both in terms of size of the premises - 17 units are smaller than $100 \mathrm{~m}^{2}$ (Figure 10) - and of the staff involved - 16 units 
employ between 1 and 5 people (Figure 11). This can be considered another sign of the sophisticated and not mainstream nature of the activities located in the LX Factory. As in the rest of the district, the phenomenon known as "disneyfication" - the dominance of major international trade brands, often aimed at mass tourist flows - does not seem to be taking place in the LX Factory (see at regard Zarrilli et al., 2019). Assessment of LX Factory context - First of all, the interviewees have been asked to give a score from 1 to 5 (according to a Likert scale, where 1 is "very bad" and 5 is "very good") to four features which may have influenced the decision to place their business in LX Factory (accessibility, rental cost, prestige, brand). According to the results of the survey, the main reasons seem to be related to the image and the attractiveness of this latter: the categories "brand" and "prestige" receive the highest rank (3.8), while "accessibility" and "rental cost" get a lower evaluation (3.1) (Figure 12). Anyway, the level of satisfaction with the decision made is quite high: 25 respondents gave a score of 4 or 5, with an average score of 4.1 (Figure 13).



Figure 13. Level of satisfaction/no. of units (Source: authors)

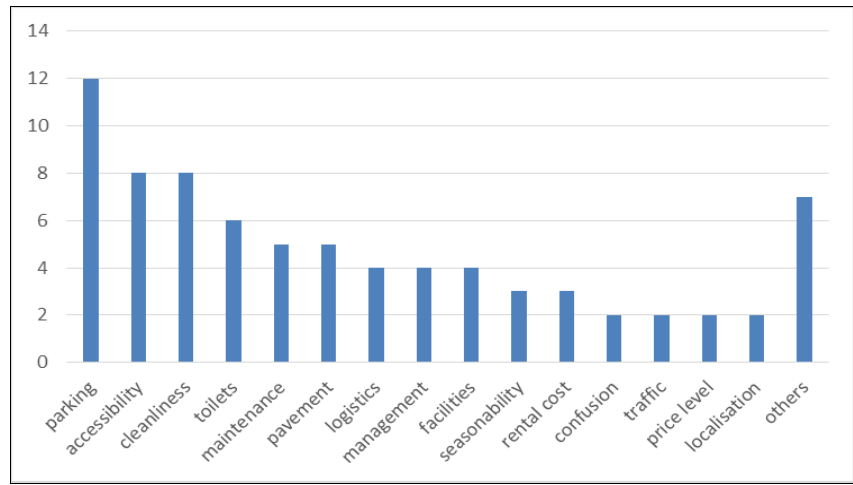

Figure 15. Main negative aspects

(3 possible answers)/no. of answers (Source: authors)

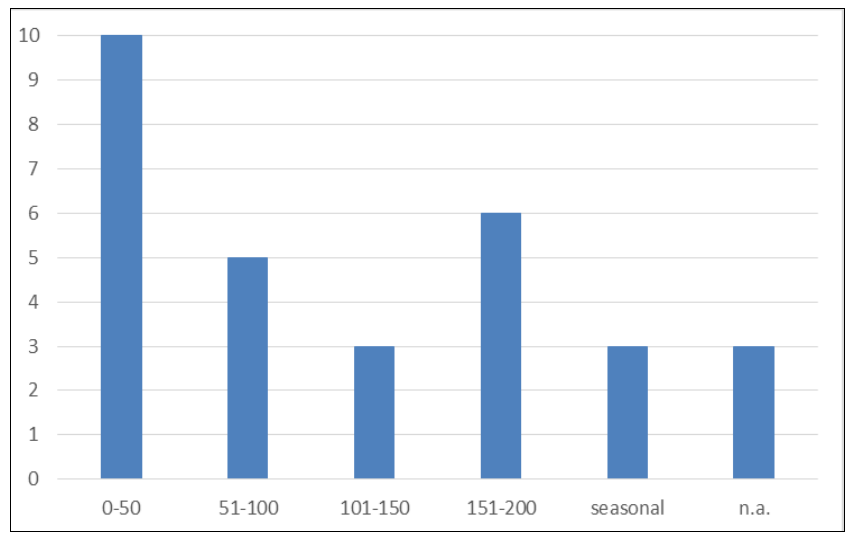

Figure 17. Average no. of visitors/customers during workdays (Source: authors)

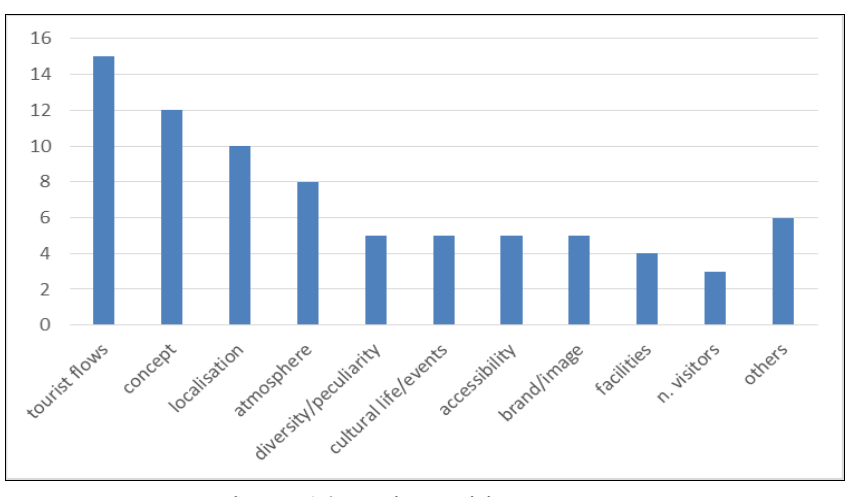

Figure 14. Main positive aspects

(3 possible answers)/no. of answers (Source: authors)

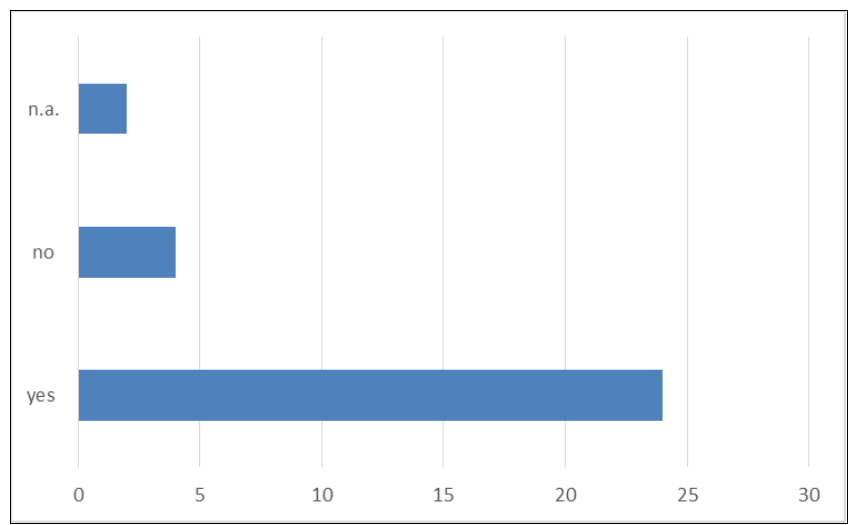

Figure 16. Pedestrianisation/no. of answers (Source: authors)

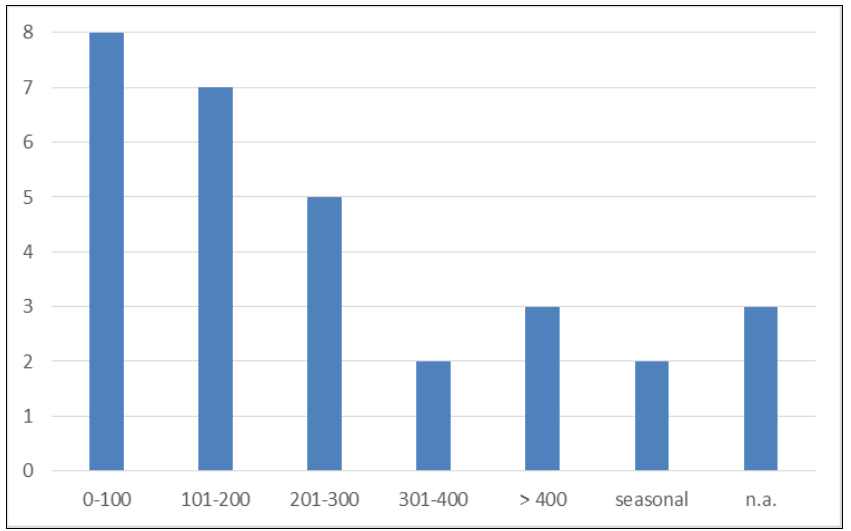

Figure 18. Average no. of visitors/customers during weekends/holidays (Source: authors)

The capacity to attract tourist flows is perceived by shop owners as by far the most positive feature, followed by the "concept" underlying LX Factory (Figure 14), which is consistent with what was stated above regarding image and attractiveness. On the other hand, many aspects related to the organisation and functioning of the structure are perceived negatively (Figure 15). We are talking in the first place about the parking area, which is inappropriate to the flow of visitors, as well as it is accessible from the main street that should be reserved for pedestrians. At this regard, there is a consensus of the respondents towards the complete pedestrianisation of the structure (Figure 16). However, aspects like 
cleanliness, toilets, maintenance, and pavement preservation are perceived negatively as well, and this is a clear sign of discontent towards the management board that hesitates to make the necessary investments to update the facilities.

Customers - Predictably, the average number of visitors/customers more than doubles during weekends and holidays (Figure 17-18). However, it is reasonable to assume that during weekends the increase is due to both residents and tourists, while during holidays - especially in the summertime- the bulk of the increase is due to the latter, because many of the former left the city for vacations. According to the respondents, the percentage of foreign tourists out of the clientele is very high. For half of the interviewees, it is between 61 and $80 \%$, and for another 7 respondents it exceeds $80 \%$ (Figure 19). France, Spain, Germany, UK, Italy, and The Netherlands are the main European countries of origin. Among extra-European countries, USA and Brazil are at the top, followed by Southeast Asian ones, presumably Japan, China, and South Korea (Figure 20). It can be noted that such national composition of foreign visitors/customers is mostly consistent with the official data, provided by Turismo de Portugal, relating to the arrivals of foreign tourists in the city of Lisbon (Figure 21), shown here for comparison.

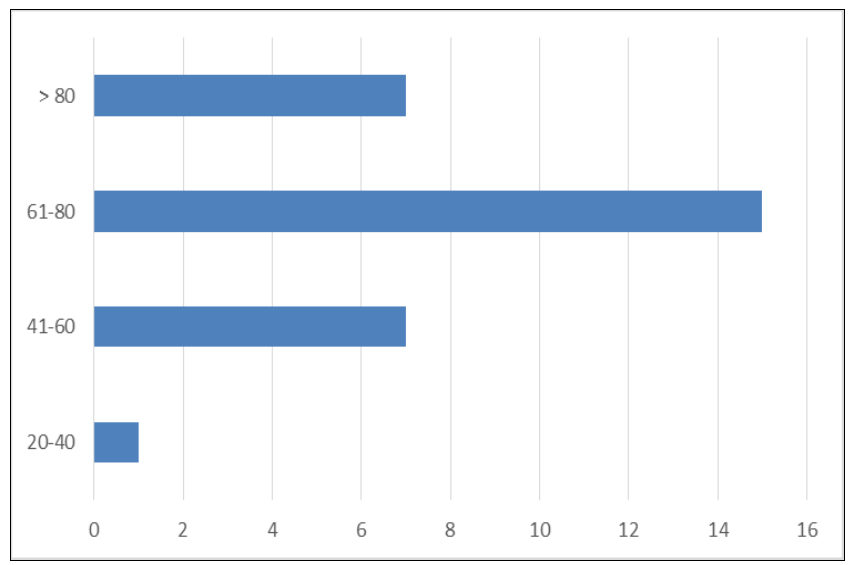

Figure 19. Percentage of foreign clientele/no. of units

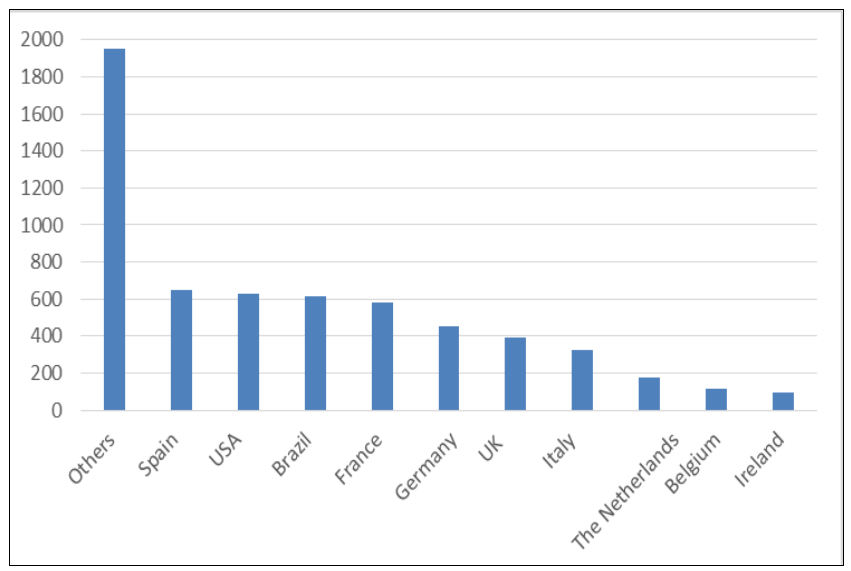

Figure 21. Foreign tourists in Lisbon. Arrivals by country 2019 (000) (Source: Insituto Nacional de EstatísticaNational Institute of Statistics) ${ }^{4}$

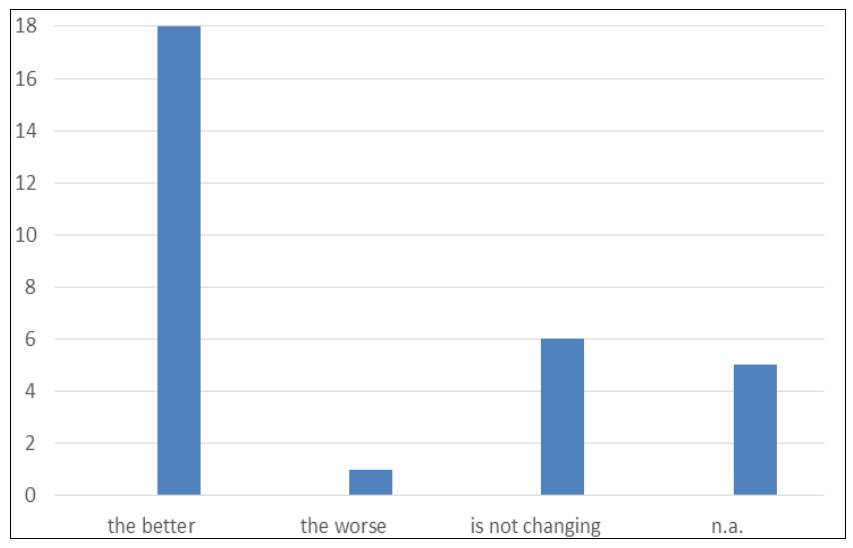

Figure 23. Alcântara district is changing for (Source: authors)

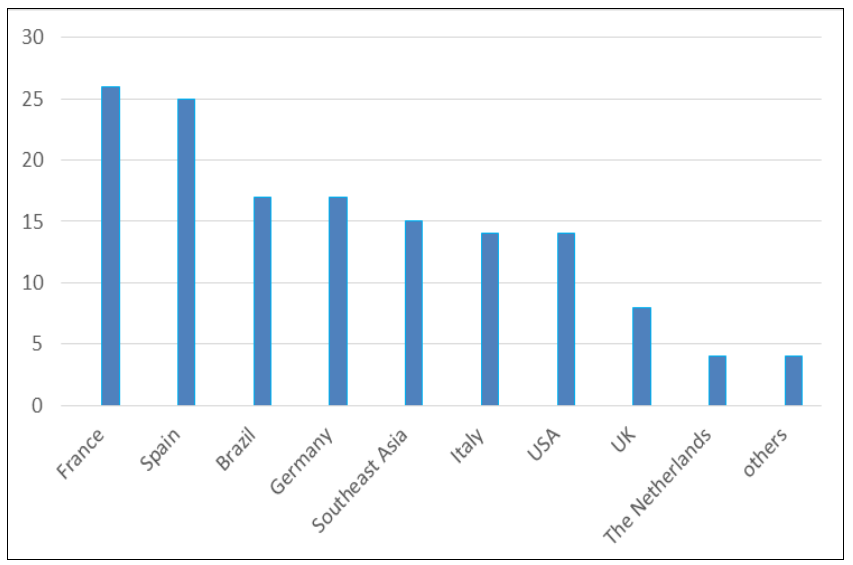

Figure 20. Main countries/regions of origin (5 answers)

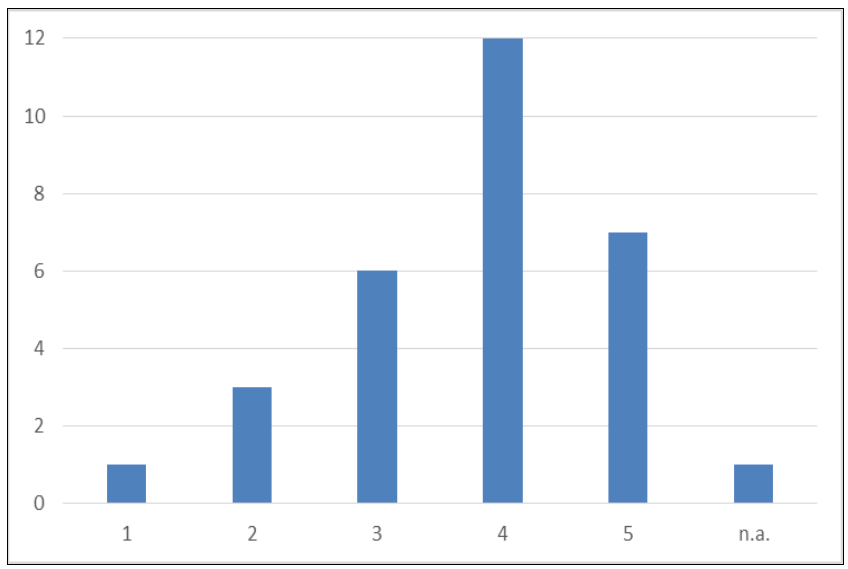

Figure 22. Tourist potential in Alcântara district Assessment/no. of answers (Source: authors)

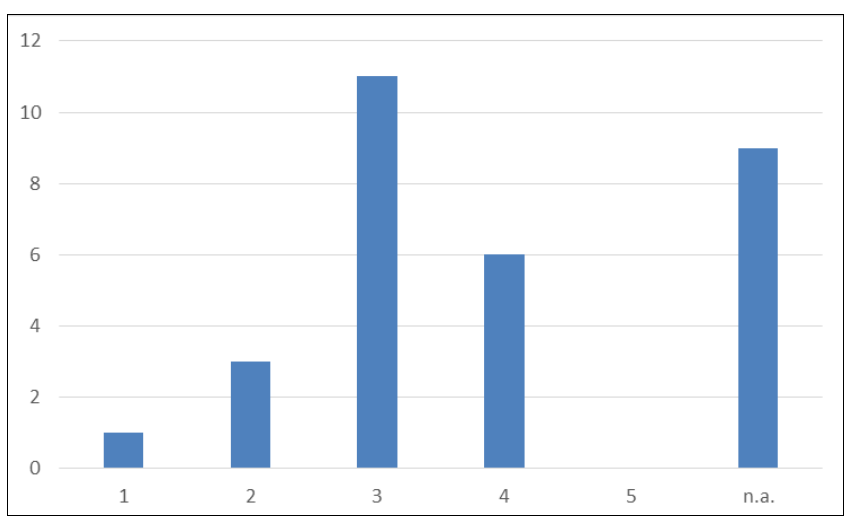

Figure 24. Evaluation of the public policies for the district Assessment/no. of answers (Source: authors) 
Alcântara neighbourhood - To understand the tourist development of the LX Factory, one cannot ignore the evolution that is taking place in the district, as mentioned above. We therefore considered useful to include this issue in the questionnaire, and the findings are quite interesting. There is a widespread perception by the respondents that the tourist potential of Alcântara is high, with 19 respondents giving a score of 4 or 5 (Figure 22). At the same time, a similar number of respondents (18) believe that the district is evolving in a positive direction (Figure 23), and it is likely that tourism development is perceived as a non-secondary factor of this change for the better. However, in the perception of the shop owners, this positive evolution seems to be due to private initiatives and a spontaneous development in the first place. Public policies for the district are less important, considering the fact that the respondent's judgment on the latter is lukewarm at best - only 6 respondents show some enthusiasm, giving a score of 4; 11 interviewees give an average evaluation of 3; 3 of them give a low evaluation of 1 or 2, while 9 don't answer at all (Figure 24). This last circumstance could also be due to the fact that some, maybe many, shop owners are not resident in Alcântara, so they do not have a real awareness or interest in the evolution of the district.

There is no doubt that LX Factory is establishing itself as the main tourist attraction of Alcântara. At this last regard, it is possible to mention a previous survey that has been carried out in the months of March and April 2018 to a sample of 303 tourists visiting the district, aimed at understanding their motivations and assessment (Zarrilli et al., 2019). The findings showed that Alcântara is especially popular with young tourists looking for trendy places, such as LX Factory. At this regard, the answers to the question "motivations for visiting Alcântara" (Figure 25) gave a clear indication in this sense. A first group of answers (99 responses) referred to a generic motivation, namely the visit to the district (curiosity, desire to return, to go for a walk, because perceived Alcântara as fashionable, on the advice of friends and specialised media). However, the by far prevalent specific reason, with 89 responses (equal to 29.4\%), turned out to be the visit to LX Factory. To these 89 answers we should perhaps add the 10 respondents (3.3\%) who indicated shopping as the reason for their visit, which most likely will have taken place in the LX Factory, where most of the shops of interest to tourists are located.

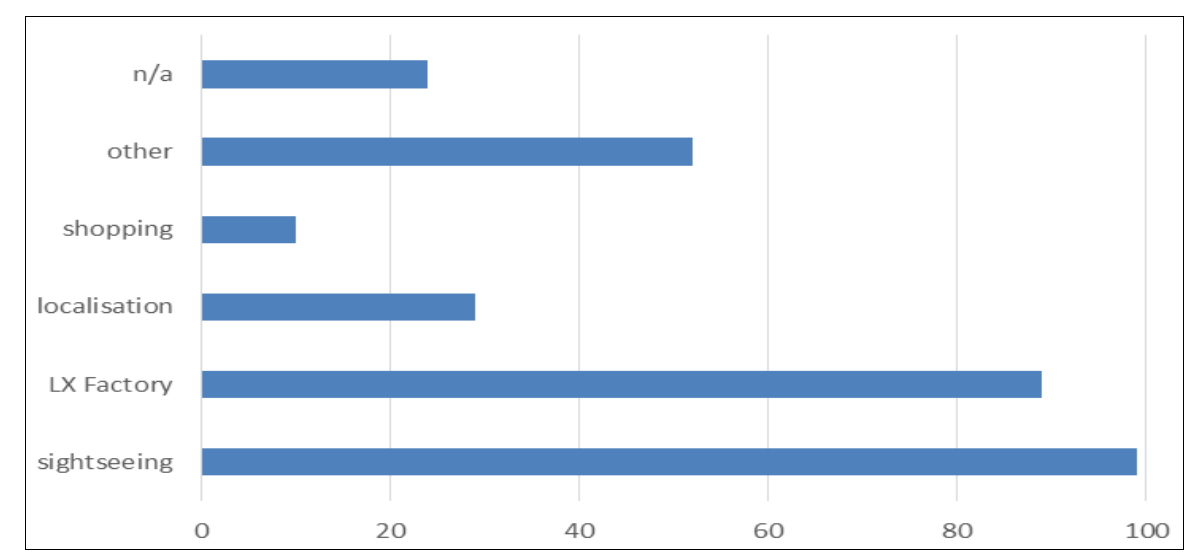

Figure 25. Motivations for visiting Alcântara/no. of answers (Source: authors)

\section{CONCLUSION}

Alcântara is currently a neighbourhood of contrasts, and it seems to be also an emerging tourist area in Lisbon, still authentic but with an image of dynamism and transformation. Its barycentric location between two strong tourist areas, the historic centre and Belém, and its good accessibility, which can still be improved, contribute to the predictable future development of the area. Among the diversified tourist attractions of Alcântara, such as museums, religious buildings and restaurants, the former factories and the industrial landscape seem to be particularly appealing.

Alcântara is going through a process of regeneration. This process includes touristification, i.e. the introduction in the neighbourhood of several tourist attractions, among them LX Factory, as well as the construction of superstructures, such as apartments and a hospital that can be seen as signs of gentrification. The LX Factory is undoubtedly the most important attraction in the neighbourhood, both for Portuguese and foreigners with its small but trendy shops and events. It brought an artistic and intellectual contemporaneity not only for its perimeter but to the whole district. Arguably, tourism is playing a key role in the success of LX Factory as a growing leisure destination. Several elements allow us to state the following: there is a high satisfaction and the very positive assessment of the shop owners on the capacity of LX Factory to attract tourist flows, thanks to its innovative concept and its captivating image; most costumers are foreign tourists; the shop owners highly appreciate the tourism evolution of Alcântara, which is obviously having a positive impact on the turnover of the shops located in the LX Factory; the motivations of the tourists interviewed in our previous survey also indicate LX Factory as the main specific reason for a visit to the district of Alcântara.

Further studies on Alcântara should consider the effects of gentrification and touristification on the neighbourhood, two issues that are becoming increasingly evident when walking and visiting this area of Lisbon.

\section{REFERENCES}

Ashworth, G.J., \& Tunbridge, J.E. (2000). The Tourist historic City. Retrospect and Prospect of Managing the Heritage City. Pergamon, Amsterdam, The Netherlands.

Barata Salgueiro, T., Mendes, L., \& Guimarães, P. (2017). Tourism and urban changes: lessons from Lisbon. In M. Maria Gravari-Barbas \& S. Guinand (Eds.), Tourism and Gentrification in Contemporary Metropolises. International Perspectives, 255-275, Routledge, Oxon, UK. 
Brito-Henriques, E. (1996). A Lisboa turística, entre o imaginário e a cidade. A construção de um lugar turístico urbano [Touristic Lisbon, between imagery and city. The construction of an urban tourist place]. Ed. Colibri, Lisbon, Portugal (in Portuguese).

Brito, L.M., Cappucci, M., \& Zarrilli, L. (2015a). Lisbon (e)Motions: A survey on the experiences of group travelling tourists, based on the information given by their guides. In L.M. Brito \& M. Soares (Eds.), Abstracts \& Selected Papers eBook. 4th International Research Forum on Guided Tours, Estoril, 55-78, Escola Superior de Hotelaria e Turismo do Estoril, Estoril, Portugal.

Brito, L.M., Zarrilli, L., \& Cappucci, M. (2015b). A perceção turística de Lisboa: Imagem, mobilidade e qualidade de vida [The tourist perception of Lisbon: Image, mobility and quality of life]. Revista Turismo \& Desenvolvimento, 24, 69-81 (in Portuguese).

Bujok, P., Rodriguez González, M.A., Klempa, M., Jelinek, J., \& Porzer, M. (2014). Industrial Tourism and the Sustainability of the Development of Tourism Business. Tourism Education Studies and Practice, 3, 88-97. https://doi.org/10.13187/tesp.2014.3.88

Bujok, P., Klempa, M., Jelinek, J., Porzer, M., \& Rodriguez González, M.A. (2015). Industrial Tourism in the Context of the Industrial Heritage. GeoJournal of Tourism and Geosites, 1, 81-93. http://gtg.webhost.uoradea.ro/PDF/GTG-1-2015/7_174_Porzer.pdf

Chmielewska, M., \& Lamparska, M. (2012). Post-Industrial Tourism as a Chance to Develop Cities in Traditional Industrial Regions in Europe. Sociologie Româneascâ, 3, 67-75. https://doi.org/10.3390/su13158145

Ferreira, J. (2017). Arrendatários do LX Factory surpreendidos com compra do espaço por grupo francês [LX Factory tenants surprised by French group purchase of space]. Jornal Público, 13 de setembro, (in Portuguese). https://www.publico.pt/2017/09/13 /local/noticia/arrendatarios-do-lx-factory-surpresos-com-compra-do-espaco-por-grupo-frances-1785353

Gelbman, A. (2007). Tourism in Industry in the Post-Industrial City. In P. Duhamel, \& R. Knafou (Eds.), Mondes urbains du tourisme [Urban worlds of tourism] (pp. 151-162). Belin, Paris, France.

Guimarães, P. (2016). A eficácia dos projetos especiais de urbanismo comercial. Evidências de Braga [The effectiveness of special commercial urbanism projects. Braga Evidence]. Finisterra - Revista Portuguesa de Geografia, 102, 47-64 (in Portuguese). https://doi.org/10.18055/Finis7320

Hackworth, J. (2006). The Neoliberal City. Governance, Ideology, and Development in American Urbanism. Cornell University Press, Ithaca, USA.

Jansen-Verbeke, M., \& Lievois, E. (1999). Analysing heritage resources for urban tourism in European cities. In D. G. Pearce, \& Richard W. Butler (Eds.), Contemporary issues in tourism development (pp. 81-106). Routledge, Abingdon, UK.

Joaquim, G. (2019). Tourfly. Inovação e futuro: contributos para o Desenho da Oferta Turística na AML [Tourfly. Innovation and the future: Contributions to the Design of the Tourist Offer in LMA]. Escola Superior de Hotelaria e Turismo do Estoril, Estoril, Portugal (in Portuguese).

Kolb, B. (2006). Tourism Marketing for Cities and Towns: Using Branding and Events to Attract Tourists. Butterworth Heinemann, Oxford, UK.

Marques de Abreu Pereira, B.R. (2009). O vale de Alcântara como caso de estudo. Evolução da morfologia urbana, [The Alcântara Valley as a case study. Evolution of urban morphology], Unpublished Master thesis, Universidade Técnica de Lisboa, Lisbon, Portugal (in Portuguese).

Mendes, L. (2013). Public Policies on Urban Rehabilitation and their Effects on Gentrification in Lisbon. AGIR - Revista Interdisciplinar de Ciências Sociais e Humanas, 5, 200-218.

Moore, R. (2017). How down-at-heel Lisbon became the new capital of cool. The Guardian.

Muselaers, M. (2017). Touristifying Mouraria. The Impacts of Touristification and Responses of the Local Community, Unpublished Master thesis, Utrecht University, The Netherlands.

Nofre, J. (2013). Vintage Nightlife: Gentrifying Lisbon downtown. Fennia, 2, 106-121. https://doi.org/10.11143/8231

Orbasli, A. (2000). Tourists in Historic Towns. Urban Conservation and Heritage Management. E \& FN Spon, New York, USA.

Ribeiro, C. (2012). Reabilitação Urbana e Sustentabilidade. LX Factory: um exemplo de reabilitação sustentável na cidade de Lisboa [Urban Rehabilitation and Sustainability. LX Factory: an example of sustainable rehabilitation in the city of Lisbon]. Unpublished Master thesis. Universidade Técnica de Lisboa, Lisbon, Portugal (in Portuguese).

Rodrigues da Silveira, C. (2017). A transformação da área industrial de Alcântara. Dois casos de estudo: Alcântara-rio e LX Factory, [The transformation of the industrial area of Alcântara. Two case studies: Alcântara-rio and LX Factory]. Unpublished Master Thesis, Universidade Lusíada de Lisboa, Lisbon, Portugal (in Portuguese).

Safara, J., \& Brito-Henriques, E. (2017). O Hotel Santiago de Alfama como alegoria da política recente de regeneração urbana [The Hotel Santiago de Alfama as an allegory of the recent policy of urban regeneration]. Finisterra - Revista Portuguesa de Geografia, 106, 65-84 (in Portuguese). https://doi.org/10.18055/Finis12010

Sequera, J., \& Nofre, J. (2018). Shaken, not Stirred. New Debates on Touristification and the Limits of Gentrification. City, 5-6, 843-855. https://doi.org/10.1080/13604813.2018.1548819

Tallon, A. (2010). Urban Regeneration in the UK. Routledge, Abingdon, UK.

Tiesdell, S., Taner, O., \& Heath, T. (1996). Revitalizing Historic Urban Quarters, Butterworth-Heinemann, Oxford, UK.

Tulumello, S. (2015). Reconsidering Neoliberal Urban Planning in Times of Crisis: Urban Regeneration Policy in a «Dense» Space in Lisbon. Urban Geography, 1, 1-24. https://doi.org/10.1080/02723638.2015.1056605

Vidal, F. (2014). Urban Transformation and Diffusion of Tourism Practices: Visiting Alcântara at the Turn of the Twentieth Century. Journal of Tourism and Cultural Change. 2, 118-132. https://doi.org/10.1080/14766825.2014.915086

Vidal, F. (2015). Sociability and Collective Action in a Lisbon Work-Class Neighbourhood: The Social Representations of Alcântara in the Early Twentieth Century, Portuguese Journal of Social Science, 2, 143-156. https://doi.org/10.1386/pjss.14.2.143_1

Xie, P.F. (2015). Industrial Heritage Tourism. Channel View Publications, Bristol, UK.

Zarrilli, L., \& Brito, L.M. (2013). Lisbon Experience. Mobility, Quality of Life and Tourist Image: A Survey. Geojournal of Tourism and Geosites, 2, 2-12. http://gtg.webhost.uoradea.ro/PDF/GTG-2-2013/11_138_Zarrilli_Brito.pdf

Zarrilli, L., \& Brito, L.M. (2017). Lisbon and the Alcântara Neighbourhood Changes: Is Tourism Invading or Renovating? Geojournal of Tourism and Geosites, 2, 254-271. http://gtg.webhost.uoradea.ro/PDF/GTG-2-2017/253_Zarrili.pdf

Zarrilli, L., Brito, M., \& Cappucci, M. (2019). Alcântara (Lisbona), da quartiere industriale a destinazione turistica: offerta turistica, strutture ricettive e valutazione del quartiere [Alcântara (Lisbon), from industrial district to tourist destination: tourist offer, accommodation facilities and evaluation of the neighbourhood]. Geotema, Supplemento 2019, 67-81, (in Italian).

Zukin, S. (2010). The Naked City: The Death and Life of Authentic Urban Places. Oxford University Press, Oxford, UK.

*** Bondora (2019). How touristification is destroying European cities. https://www.bondora.com/blog/how-touristification-isdestroying-european-cities/ 